\title{
Quantifying the Effects of Pipeline Installation on Agricultural Productivity in West China
}

\author{
Peng Shi, Yong Huang, Hong-Bo Chen, Ya-Feng Wang, Jun Xiao, and Li-Ding Chen*
}

\begin{abstract}
Pipeline construction can have considerable effects on agro-ecosystems. However, little research has documented pipeline installation disturbance on agricultural productivity. We sampled three sites in agricultural regions of West China in Gansu and Shaanxi provinces to study the effects of pipeline installation disturbance on crop productivity. Corn yield and five crop grow th characteristics were measured and analyzed at six different distances on both sides of a pipeline at two sites: 0 (trench), 10 (piling or working zone), 20,50, and $100 \mathrm{~m}$. Crop productivity was assessed at a third site by sampling across pipelines at three different times after their construction $(2,6$, and $8 \mathrm{yr})$. The results showed that agricultural productivity was mainly impaired inside the $20 \mathrm{~m}$ on both sides of the pipeline. The level of disturbance on agriculture productivity decreased as distance from pipeline increased. Crop productivity in the affected zones is expected to gradually improve over time. Pipeline installation had significant effect on soil organic matter, $\mathrm{N}$ content, and $\mathrm{pH}$, and correlated with crop growth characteristics. Proper soil management practices, such as storing and backfilling topsoil separately from subsurface soil during the installation process, should be addressed to reduce the impacts of pipeline installation on crop productivity.
\end{abstract}

Installation of gas or oil pipelines has increased substantially in recent years. Currently, China is building a network of natural gas and oil pipelines, which has reached $82,000 \mathrm{~km}$ long at the end of 2010 and is expected to be doubled by 2015. Inevitably, China's pipeline installation will lead to a series of ecological and environmental issues when pipelines pass through agricultural areas. During the construction period, vegetation clearance and topsoil removal in the pipeline's right-of-way (RoW) can significantly affect soil quality (Yu et al., 2010). Various studies have indicated that pipeline installation would change soil physical and chemical properties in the surrounding area (Olson and Doherty, 2012; Shi et al., 2014). Agricultural ecosystems provide food essential to human wellbeing (Swinton et al., 2007). Despite the worldwide expansion of pipelines and increasing recognition of their potential environmental effects (Boboye and Abumere, 2014; Doherty and Otitoloju, 2013), relatively little is reported on the impact of pipeline installation on agricultural productivity.

Assessing the effects of pipeline construction on agricultural productivity is important for developing state-required

P. Shi, Y.-F. Wang, J. Xiao, and L.-D. Chen, State Key Lab. of Urban and Regional Ecology, Research Center for Eco-Environmental Sciences, Chinese Academy of Sciences, Beijing 100085, China; current address: P. Shi, and J. Xiao, Univ. of Chinese Academy of Sciences, Beijing 100049, China; and Y. Huang, and H.-B. Chen, Centre for Environmental Engineering Evaluation, Ministry of Environmental Protection of PRC, Beijing 100012, China. Received 13 Jan. 2014. Accepted 19 Oct. 2014. ${ }^{*}$ Corresponding author: (liding@rcees.ac.cn).

Published in Agron. J. 107:524-531 (2015)

doi:10.2134/agronj14.0023

Copyright (c) 2015 by the American Society of Agronomy, 5585 Guilford Road, Madison, WI 53711. All rights reserved. No part of this periodical may be reproduced or transmitted in any form or by any means, electronic or mechanical, including photocopying, recording, or any information storage and retrieval system, without permission in writing from the publisher. environmental impact assessments (EIA) (Karstens et al., 2007). The pipeline's RoW is generally considered the boundary of disturbance when a pipeline is installed through an agricultural area (Desserud et al., 2010). However, effects of construction on the agro-ecosystem may vary in different pipeline zones (Shi et al., 2014). The pipeline corridor, which includes trench, piling, and work areas, accounts for various anthropogenic activities with different levels of disturbance such as soil compaction in the working area and soil nutrient loss in the trenched area (Landsburg, 1989). In addition, the existing assessment boundary within the pipeline's RoW may not adequately encompass all of the construction effects, and the disturbance may extend beyond pipeline's RoW. The accurate spatial extent of the assessment was crucial to quantitative EIA (João, 2002). By determining the boundary of the pipeline project's disturbed zone, practitioners could control the quality of EIA (Karstens et al., 2007). Farmland in the pipeline zones may be improved over time. Soils in the disturbed zones will undergo rehabilitation following pipeline installation as a result of cropping and fertilization (Soon et al., 2000b). The determination of the intensity of disturbance over time after pipeline installation could provide a basis for the follow-up mitigation and improve the effectiveness of compensation (Shi et al., 2014). However, the important issue of productivity improvement is rarely addressed in EIA.

The level of disturbance resulting from pipeline installation may depend on several factors such as soil condition (Soon et

Abbreviations: AN, alkali-hydrolyzable nitrogen; AP, soil available phosphorus; CNPC, China National Petroleum Corporation; EIA, environmental impact assessments; RDA, redundancy analysis; RoW, pipeline right-of-way; SOM, soil organic matter; TC, total carbon; TK, total potassium; TN, total nitrogen; TP, total phosphorus; WT, soil water content. 
al., 2000b), installation method (Bayramov et al., 2012), and equipment used during construction (Shi et al., 2014). Studies have shown that trenching for pipeline installation decreased soil quality by more than $50 \%$ compared to the undisturbed areas (Shi et al., 2014). Soon et al. (2000a) documented a reduction in soil organic $\mathrm{C}$ by about $20 \%$ after pipeline construction and soil total nitrogen (TN) was reduced by $29 \%$ or more in the RoW. However, the factors influenced by pipeline installation that contribute to yield reduction have not been well-documented.

In this study, we determined the spatial extent and quantified the effects of pipeline disturbance on crop productivity over time by examining the crop and soil characteristics across the pipeline over multiple time periods after installation. We hypothesized that disturbance intensity would be different across the different pipeline construction zones and agricultural productivity would be improved over time after pipeline installation.

\section{MATERIAL AND METHODS}

\section{Study Area: West-to-East Pipelines}

The nearly $4000 \mathrm{~km}$ long, $1016 \mathrm{~mm}$ diam. West-to-East Gas Pipeline I traverses nine provinces from Xinjiang to Shanghai.
It is the first large pipeline project in China, and the pipeline was put into service in 2004. Another natural gas pipeline, the $4843 \mathrm{~km}$ West-to-East Gas Pipeline II (1016 mm diam.), was constructed in 2010. The $2000 \mathrm{~km}$ long West Crude Oil Pipeline with a $711 \mathrm{~mm}$ diam. was built in 2006 and runs from Urumqi, in the Xinjiang Uygur Autonomous Region to Lanzhou, in Gansu province. Up to Gansu, the three pipelines run parallel to each other (Fig. 1). Pipeline construction period in a given location was about 3 mo. All three pipelines were built by the China National Petroleum Corporation (CNPC). Pipeline routes in the middle of agricultural land were addressed by CNPC before construction and the three pipelines were located $100 \mathrm{~m}$ apart from each other.

We sampled three sites in this study: one each in Pingliang (Site A), Xi'an (Site B), and Zhangye (Site C), all of them are located in agricultural regions of West China dominated by corn (Zea mays L.). At Site A, the average annual air temperature in 2012 was $8.8^{\circ} \mathrm{C}$, with the mean monthly lowest and highest temperatures observed in January $\left(-4.6^{\circ} \mathrm{C}\right)$ and July $\left(21.1^{\circ} \mathrm{C}\right)$, respectively. The average annual precipitation in this region was $482 \mathrm{~mm}$, mostly occurred in the summer season from June to late September. Site B belongs to the warmtemperate, subhumid, continental monsoon climate zone,
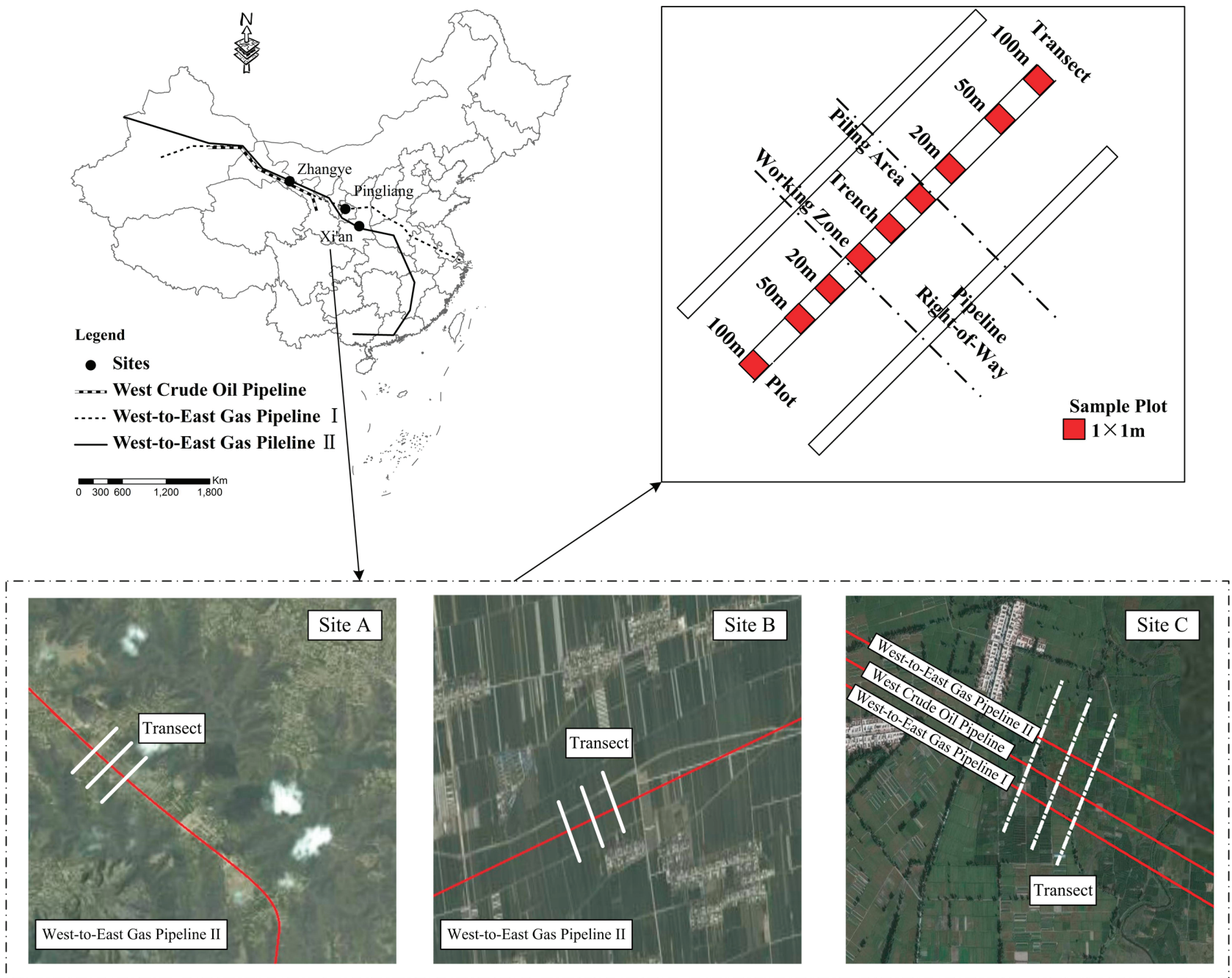

Fig. I. Transects in three sites were laid out for crop sampling along West-to-East Gas Pipeline I, West-to-East Gas Pipeline II, and West Crude Oil Pipeline in 2012. Site A is located in Pingliang (Gansu province, China), Site B in Xi'an (Shaanxi province, China), and Site C in Zhangye (Gansu province, China). 
with an average annual air temperature of $13.6^{\circ} \mathrm{C}$ in 2012 . The average maximum and minimum air temperatures were $27.1^{\circ} \mathrm{C}$ in June and $0.8^{\circ} \mathrm{C}$ in January, respectively. The average annual precipitation in this region was $613.7 \mathrm{~mm}$, most of which occurred in summer months (July, August, and September). The average annual air temperature at site $\mathrm{C}$ was $7^{\circ} \mathrm{C}$, with the mean monthly lowest air temperature of $-9.2^{\circ} \mathrm{C}$ in January and the mean monthly highest air temperature of $21.5^{\circ} \mathrm{C}$ in July. The average annual precipitation at Site C was $130 \mathrm{~mm}, 60$ to $70 \%$ of which occurred in maize growing seasons from June to August. The West-to-East Gas Pipeline II passes through Sites A and B, and all three pipelines pass through Site C. Sites A and $B$ were selected to determine the spatial extent of pipeline disturbance on agricultural productivity, and Site $\mathrm{C}$ was used to assess the time to recovery (the three parallel pipelines West-to-East Gas Pipeline I, West Crude Oil Pipeline, and West-to-East Gas Pipeline II had recovery periods of 8, 6, and 2 yr, respectively). Site A mainly comprises loess with texture ranging from fine silt to silt, located in a hilly region with a gentle slope of $10 \%$. Site B has sandy loam-textured soil and the topography is almost flat $(0-1 \%)$ throughout the site area. Site $\mathrm{C}$ is also flat with bleached, sandy textured soil.

\section{Sampling Method}

The pipeline's RoW (with a width about $30 \mathrm{~m}$ for natural gas or oil pipeline corridors) for different operations is divided into three zones: trench, piling, and working areas (Fig. 2). The trench comprises a 2-m wide channel in which the pipeline is buried (in the middle of the RoW), the working area is used for vehicular traffic and operations (about $15 \mathrm{~m}$ from one side of the trench), and the piling area is cleared to stockpile soil excavated from the trench (about $10 \mathrm{~m}$ from the other side of the trench). Before sampling, we conducted a survey to confirm that crop cultivation and fertilization were similar in the sampling area at each site. The corn variety at Sites A and C was a single hybrid (Yedan-2) and corn planted at Site B was a triple-cross hybrid (Hudan-2). The densities of seeding at Sites A, B and C were 5.2, 6.5 and 6.8 plants per $\mathrm{m}^{2}$, respectively. Fertilizer application rates at Sites $\mathrm{A}, \mathrm{B}$, and $\mathrm{C}$ were similar with 140 to $150 \mathrm{~kg} \mathrm{~N} \mathrm{ha}^{-1}, 70$ to $75 \mathrm{~kg}$ $\mathrm{P}_{2} \mathrm{O}_{5} \mathrm{ha}^{-1}$, and 35 to $37 \mathrm{~kg} \mathrm{~K}_{2} \mathrm{O} \mathrm{ha}^{-1}$, respectively. In August 2012, we set up three transects perpendicular to the pipeline at each site with similar topography and soil characteristics, at least $500 \mathrm{~m}$ apart. Transect is a classical sampling method commonly used for ecological and environmental monitoring in linear projects for EIA purposes (Cui et al., 2009; Desserud et al., 2010). Two 1 by $1 \mathrm{~m}$ plots were laid out for crop and topsoil $(0-20 \mathrm{~cm})$ sampling within trench, piling, and working zones along each transect. Plots were also located at 20, 50, and $100 \mathrm{~m}$ from both sides of pipeline at Sites A and B, and set at 20 and 50 $\mathrm{m}$ of three paralleling pipelines at Site C (Fig. 1). Plant height, stem size, corncob length, and corncob size in each plot were measured at the site while the corn and soil samples from 156 plots were taken to the laboratory for yield and chemical analysis.

\section{Laboratory Analysis}

Corn samples were heated in an oven at $105^{\circ} \mathrm{C}$ for $30 \mathrm{~min}$ and dried at $80^{\circ} \mathrm{C}$ to constant weight $(5 \mathrm{~d})$ for yield analysis. Soil samples were air-dried for $2 \mathrm{wk}$, ground, and sieved through a $2 \mathrm{~mm}$ and then a $1 \mathrm{~mm}$ screen for chemical analysis. Soil organic matter (SOM) was analyzed using colorimetric
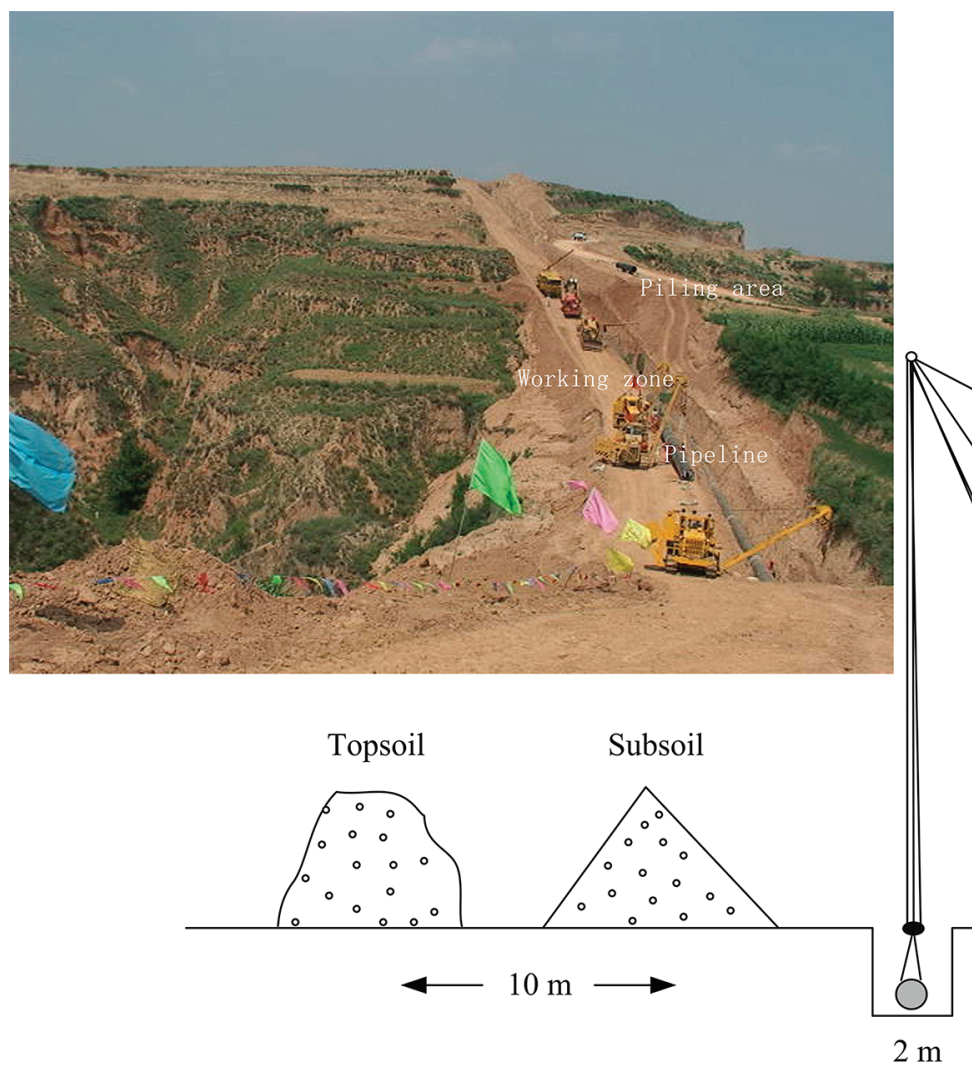

Piling area

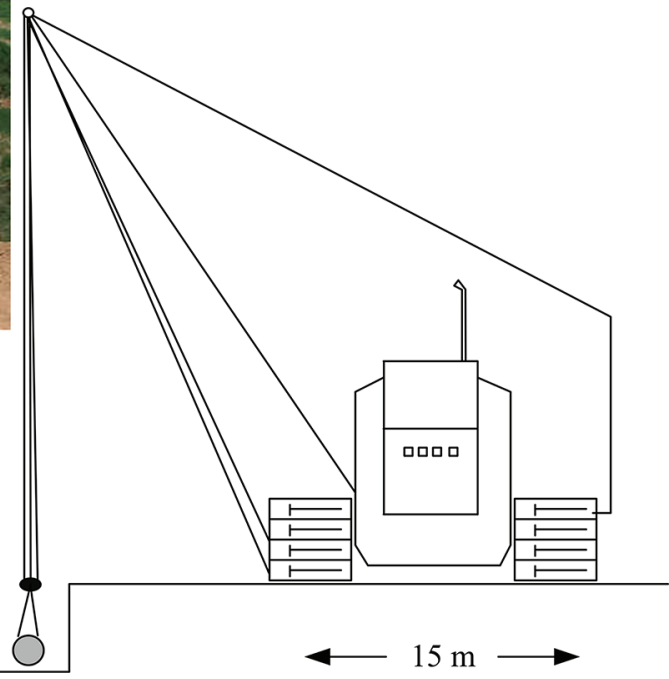

Trench
Working zone

Fig. 2. Pipeline right-of-way, including the trench, piling, and working areas. 
determination (Sims and Haby, 1971). Total nitrogen and total carbon (TC) were determined using an elemental analyzer (Vario EL III, Elementar Analysensysteme GmbH, Hanau, Germany). Total phosphorus (TP) and total potassium (TK) were extracted by microwave digestion and measured using inductively coupled plasma optical emission spectrometry (Agilent Technologies, Santa Clara, CA). Alkali-hydrolyzable nitrogen (AN) was analyzed using the method described by Cornfield (1960). Soil available phosphorus (AP) was measured by the extraction method. Soil particle size was analyzed using the MasterSizer 2000 apparatus (Malvern Instruments Ltd., Malvern, UK) to calculate the proportion of clay $(<0.002$ $\mathrm{mm}$ ). Soil $\mathrm{pH}$ was measured at a soil/water ratio of 1:2.5 using a Crison GLP 21 pH meter (Crison Instruments, Barcelona, Spain). Soil water content (WT) was measured by WET-2 (Delta-T Devices, Cambridge, UK).

\section{Data Analysis}

We used the Shapiro-Wilk method to test the normality, and all data showed normal distribution $(P>0.05)$. The means of crop yield, crop measurements, and soil characteristics were compared at six distances from the pipelines at Sites A and B using one-way ANOVA in SPSS16.0 software (SPSS Inc., Chicago, IL). One-way ANOVA was also used to compare farmland recovery over multiple time periods after pipeline installation at site C. Tukey's Post-Hoc test was used to indicate whether parameters were different or similar. The redundancy analysis (RDA) was used to directly assess the relationship between crop characteristics and soil properties in CANOCO 4.5 software (Wageningen UR, Wageningen, the Netherlands). The RDA is an effective multivariate analysis approach that can be used to explore correlations between two groups, such as multispecies data and environmental characteristics (De'Ath, 2002). The plots used in the RDA were from the disturbed areas (trench, piling, and working areas) and $50 \mathrm{~m}$ from the pipeline, and the contribution of distance was not included in this analysis. Pearson Correlation was used to analysis relationship between crop characteristics and soil properties in SPSS16.0.

\section{RESULTS}

\section{Effects of Pipeline Installation on Crop Characteristics and Soil Properties}

Crop yield tended to increase with distance from the pipeline, following the pattern of pipeline's RoW $<20 \mathrm{~m}<$ $50 \mathrm{~m}$ and $100 \mathrm{~m}$ (Fig. 3). In general, the pipeline's RoW, including trench, piling, and working areas, had lower yields than other sampling distances. At Sites A and B, trenches had the lowest yields of 8.48 and $3.33 \mathrm{t} \mathrm{ha}^{-1}$, respectively. Corn yield at $20 \mathrm{~m}$ at Site B was $5.34 \mathrm{t} \mathrm{ha}^{-1}$, decreased significantly $(P<0.05)$ compared to yields at 50 and $100 \mathrm{~m}$. Corn yields at 50 and $100 \mathrm{~m}$ zones were significantly higher $(P<0.05)$ than yields at the pipeline's RoW, and were almost twice as high as the trenched area of Site B. There was no significant difference in crop yields between 50 and $100 \mathrm{~m}$ at both sites.

Plant height, stem size, corncob length, corncob size, and leaf chlorophyll were all lower at pipeline's RoW than those beyond $20 \mathrm{~m}$ from the pipeline $(50$ and $100 \mathrm{~m})$ at both sites, and the difference was significant $(P<0.05)$ for plant height (Table 1$)$.

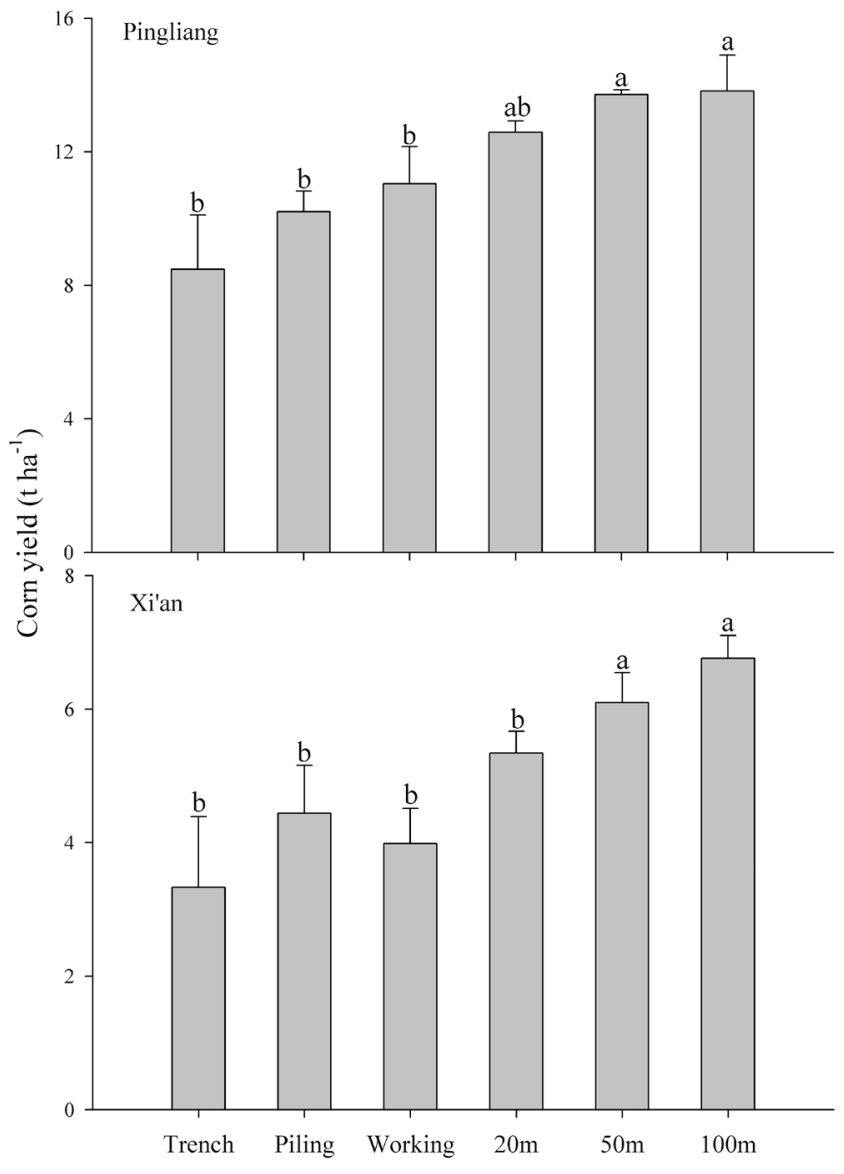

Fig. 3. Corn yields were analyzed along West-to-East Gas Pipeline II in Pingliang, Gansu province, China (Site A) and Xi'an, Shaanxi province, China (Site B) in 2012. Values followed by the same letter above standard error are not significantly different at the 0.05 level across pipeline construction zones at each site according to Tukey's post-hoc test ( $n=6$ for both sites).

The trenched area showed relatively lower plant height, corncob size, and leaf chlorophyll compared to those at other pipeline zones, with a significant decrease $(P<0.05)$ in leaf chlorophyll at Sites A and B. Plant height, corncob length and leaf chlorophyll were higher at $20 \mathrm{~m}$ from pipeline than those at the pipeline's RoW. However, values for these characteristics at $20 \mathrm{~m}$ were lower compared to those at $50 \mathrm{~m}$ or farther from the pipeline. Plant height, stem size, corncob length, and leaf chlorophyll showed no clear pattern of changes between 50 and $100 \mathrm{~m}$ from the pipeline.

Soils in trench, piling, and working areas had lower AN, AP, TN, TP, SOM, and WT than that at 50 and $100 \mathrm{~m}$ from pipelines at Sites A and B (Table 2). In particular, the levels of AN, TN, and SOM at 50 and $100 \mathrm{~m}$ from pipelines were much higher $(P<0.05)$ than those inside pipeline's RoW at both Sites A and B. The trenched area had the lowest AN, TP, and $\mathrm{SOM}$ at both sites. However, $\mathrm{pH}$ increased in the trenched area. AN, AP, TN, TP, SOM, and WT at $20 \mathrm{~m}$ from pipeline were lower than those beyond $20 \mathrm{~m}$ from pipelines at Sites A and $\mathrm{B}$. There were no statistically significant differences for soil properties between the 50 and $100 \mathrm{~m}$ areas at both sites. 
Table I Mean ( \pm standard deviation) of corn characteristics along pipeline right-of-way in Pingliang, Gansu province, China (Site A) and Xi'an, Shaanxi province, China (Site B) in 2012. Values followed by the same letter are not significantly different at the 0.05 level across pipeline construction zones at each site for a specific crop characteristic according to Tukey's Post-Hoc test ( $n=30$ for both sites).

\begin{tabular}{|c|c|c|c|c|c|c|}
\hline Site & Plot & $\begin{array}{l}\text { Plant } \\
\text { height }\end{array}$ & Stem size & Corncob length & Corncob size & $\begin{array}{c}\text { Leaf } \\
\text { chlorophyll }\end{array}$ \\
\hline & & $\longrightarrow$ & 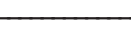 & $n$ & 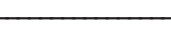 & \\
\hline \multirow[t]{6}{*}{ A } & Trench & $208.7 \pm 5.0 b$ & $2.9 \pm 0.1 \mathrm{a}$ & $27.7 \pm 1.9 a$ & $5.6 \pm 0.3 b$ & $55.5 \pm 0.2 b$ \\
\hline & Piling & $221.3 \pm 5.4 b$ & $3.0 \pm 0.3 a$ & $28.7 \pm 1.8 \mathrm{a}$ & $5.6 \pm 0.1 b$ & $58.8 \pm 0.1 \mathrm{a}$ \\
\hline & Working & $216.0 \pm 6.7 b$ & $3.1 \pm 0.4 a$ & $28.6 \pm 0.3 a$ & $5.8 \pm 0.3 \mathrm{ab}$ & $56.9 \pm 0.1 \mathrm{ab}$ \\
\hline & $20 \mathrm{~m}$ & $238.8 \pm 1.9 a$ & $2.9 \pm 0.2 \mathrm{a}$ & $28.8 \pm 1.7 \mathrm{a}$ & $6.2 \pm 0.2 a$ & $60.3 \pm 0.3 a$ \\
\hline & $50 \mathrm{~m}$ & $243.7 \pm 2.8 a$ & $3.2 \pm 0.4 a$ & $29.0 \pm 0.9 a$ & $6.5 \pm 0.1 \mathrm{a}$ & $61.6 \pm 0.2 \mathrm{a}$ \\
\hline & $100 \mathrm{~m}$ & $246.5 \pm 5.8 a$ & $3.1 \pm 0.1 a$ & $29.3 \pm 2.0 \mathrm{a}$ & $6.6 \pm 0.2 a$ & $62.3 \pm 0.3 a$ \\
\hline \multirow[t]{6}{*}{ B } & Trench & $202.3 \pm 5.8 b$ & $3.0 \pm 0.1 \mathrm{a}$ & $26.7 \pm 1.2 \mathrm{a}$ & $5.6 \pm 0.1 \mathrm{a}$ & $54.5 \pm 0.2 b$ \\
\hline & Piling & $210.0 \pm 3.0 \mathrm{ab}$ & $2.8 \pm 0.1 \mathrm{a}$ & $26.0 \pm 0.8 a$ & $5.6 \pm 0.3 a$ & $58.9 \pm 0.1 \mathrm{a}$ \\
\hline & Working & $206.0 \pm 9.2 b$ & $3.0 \pm 0.1 \mathrm{a}$ & $27.0 \pm 1.0 \mathrm{a}$ & $5.5 \pm 0.2 a$ & $57.1 \pm 0.3 a$ \\
\hline & $20 \mathrm{~m}$ & $211.0 \pm 3.8 a$ & $3.0 \pm 0.2 \mathrm{a}$ & $27.1 \pm 1.7 \mathrm{a}$ & $5.6 \pm 0.3 a$ & $57.7 \pm 0.4 a$ \\
\hline & $50 \mathrm{~m}$ & $227.0 \pm 9.9 a$ & $3.1 \pm 0.2 \mathrm{a}$ & $28.9 \pm 1.8 \mathrm{a}$ & $5.8 \pm 0.3 a$ & $59.7 \pm 0.1 \mathrm{a}$ \\
\hline & $100 \mathrm{~m}$ & $231.8 \pm 6.9 a$ & $3.1 \pm 0.1 \mathrm{a}$ & $29.0 \pm 1.5 a$ & $6.0 \pm 0.5 a$ & $59.6 \pm 0.2 a$ \\
\hline
\end{tabular}

Table 2 Mean ( \pm standard deviation) of soil properties along pipeline right-of-way in Pingliang, Gansu province, China (Site A) and Xi'an, Shaanxi province, China (Site B) in 2012. Values followed by the same letter are not significantly different at the 0.05 level across pipeline construction zones at each site for a specific soil property according to Tukey's Post-Hoc test ( $n=6$ for both sites). AN is alkali-hydrolyzable nitrogen, TN is total nitrogen, AP is available phosphorus, TP is total phosphorus, TK is total potassium, TC is total carbon, SOM is soil organic matter, and WT is soil water content.

\begin{tabular}{|c|c|c|c|c|c|c|c|c|c|c|c|}
\hline Site & Plot & $\mathrm{AN}$ & AP & $\mathrm{pH}$ & $\mathrm{TN}$ & TP & TK & $\mathrm{TC}$ & SOM & Clay & WT \\
\hline & & $\longrightarrow \mathrm{mg}$ & $\mathrm{kg}^{-1}$ & & & & $-\mathrm{g} \mathrm{kg}^{-1}$ & & + & $\longrightarrow$ & - \\
\hline \multirow[t]{6}{*}{$A$} & Trench & $22.1 \pm 1.4 b$ & $14.3 \pm 1.2 c$ & $8.27 \pm 0.13 a$ & $0.72 \pm 0.05 b$ & $0.60 \pm 0.03 a$ & $17.6 \pm 0.5 a$ & $22.1 \pm 0.9 a$ & $9.19 \pm 3.33 b$ & $19.5 \pm 0.2 \mathrm{a}$ & $19.3 \pm 0.2 \mathrm{a}$ \\
\hline & Piling & $25.2 \pm 3.3 b$ & $16.9 \pm 1.6 \mathrm{bc}$ & $8.18 \pm 0.07 a$ & $0.86 \pm 0.09 b$ & $0.62 \pm 0.06 a$ & $17.6 \pm 0.7 a$ & $23.0 \pm 1.1 \mathrm{a}$ & $11.58 \pm 1.64 b$ & $20.1 \pm 0.3 a$ & $20.1 \pm 0.1 a$ \\
\hline & Working & $23.1 \pm 4.2 b$ & $21.4 \pm 4.2 \mathrm{ab}$ & $8.20 \pm 0.09 a$ & $0.70 \pm 0.07 b$ & $0.63 \pm 0.04 a$ & $17.5 \pm 0.6 a$ & $22.2 \pm 0.1 \mathrm{a}$ & $11.56 \pm 1.64 b$ & $18.5 \pm 1.7 a$ & $18.5 \pm 0.1 \mathrm{a}$ \\
\hline & $20 \mathrm{~m}$ & $31.4 \pm 2.6 a b$ & $22.5 \pm 1.1 \mathrm{ab}$ & $8.22 \pm 0.10 a$ & $0.86 \pm 0.03 b$ & $0.65 \pm 0.02 a$ & $17.7 \pm 0.5 a$ & $22.8 \pm 0.6 a$ & $12.11 \pm 0.95 a$ & $18.7 \pm 0.3 a$ & $20.8 \pm 0.3 a$ \\
\hline & $50 \mathrm{~m}$ & $38.4 \pm 4.9 a$ & $3 \mathrm{I} . \mathrm{I} \pm 4.2 \mathrm{a}$ & $8.21 \pm 0.06 a$ & $0.94 \pm 0.02 a$ & $0.68 \pm 0.02 a$ & $16.2 \pm 0.7 \mathrm{a}$ & $22.9 \pm 0.3 a$ & $12.79 \pm 1.03 a$ & $19.5 \pm 0.6 a$ & $20.9 \pm 0.2 a$ \\
\hline & $100 \mathrm{~m}$ & $39.4 \pm 3.8 a$ & $30.4 \pm 3.7 a$ & $8.22 \pm 0.05 a$ & $0.93 \pm 0.04 a$ & $0.70 \pm 0.02 a$ & $17 . \mid \pm 0.4 a$ & $22.8 \pm 0.9 a$ & $12.98 \pm 0.94 a$ & $19.3 \pm 0.5 a$ & $20.5 \pm 0.2 a$ \\
\hline \multirow[t]{6}{*}{ B } & Trench & $15.6 \pm 0.2 c$ & $17.4 \pm 1.4 b c$ & $8.67 \pm 0.10 a$ & $0.70 \pm 0.10 b$ & $0.62 \pm 0.06 a$ & $16.9 \pm 0.7 a$ & $21.0 \pm 1.2 b$ & $11.27 \pm 2.03 b$ & $24.5 \pm 0.4 a$ & $24.8 \pm 0.2 a$ \\
\hline & Piling & $23.2 \pm 1.6 b$ & $12.4 \pm 1.7 c$ & $8.46 \pm 0.12 a$ & $0.77 \pm 0.1 \mathrm{lb}$ & $0.72 \pm 0.07 a$ & $|7.| \pm 0.9 a$ & $21.3 \pm 1.5 b$ & $12.20 \pm 2.22 b$ & $24.2 \pm 1.0 \mathrm{a}$ & $27.5 \pm 0.1 \mathrm{a}$ \\
\hline & Working & $18.2 \pm 4.6 b c$ & $19.2 \pm 1.3 \mathrm{ab}$ & $8.54 \pm 0.02 a$ & $0.69 \pm 0.1 \mathrm{Ib}$ & $0.75 \pm 0.06 a$ & $|7.| \pm 0.8 a$ & $20.9 \pm 1.5 b$ & $12.02 \pm 1.40 \mathrm{~b}$ & $22.1 \pm 0.7 a$ & $23.8 \pm 0.2 a$ \\
\hline & $20 \mathrm{~m}$ & $30.0 \pm 1.9 b$ & $24.8 \pm 3.3 \mathrm{ab}$ & $8.45 \pm 0.04 a$ & $1.33 \pm 0.08 \mathrm{a}$ & $0.94 \pm 0.05 a$ & $18 . \mid \pm 0.5 a$ & $28.9 \pm 1.2 \mathrm{a}$ & $19.81 \pm 0.14 a$ & $22.9 \pm 0.7 \mathrm{a}$ & $30.1 \pm 0.3 a$ \\
\hline & $50 \mathrm{~m}$ & $43.7 \pm 1.6 a$ & $32.6 \pm 0.8 a$ & $8.28 \pm 0.1 \mathrm{Ia}$ & $1.38 \pm 0.05 a$ & $1.09 \pm 0.02 a$ & $18.2 \pm 0.6 a$ & $28.3 \pm 0.6 a$ & $21.36 \pm 2.07 a$ & $22.0 \pm 1.2 \mathrm{a}$ & $31.3 \pm 0.2 a$ \\
\hline & $100 \mathrm{~m}$ & $40.6 \pm 1.9 a$ & $33.1 \pm 2.5 a$ & $8.32 \pm 0.05 a$ & $1.40 \pm 0.07 a$ & $1.08 \pm 0.05 a$ & $18.3 \pm 0.8 a$ & $28.6 \pm I .1 \mathrm{a}$ & $21.49 \pm 1.59 a$ & $22.8 \pm 1.0 \mathrm{a}$ & $30.8 \pm 0.2 a$ \\
\hline
\end{tabular}

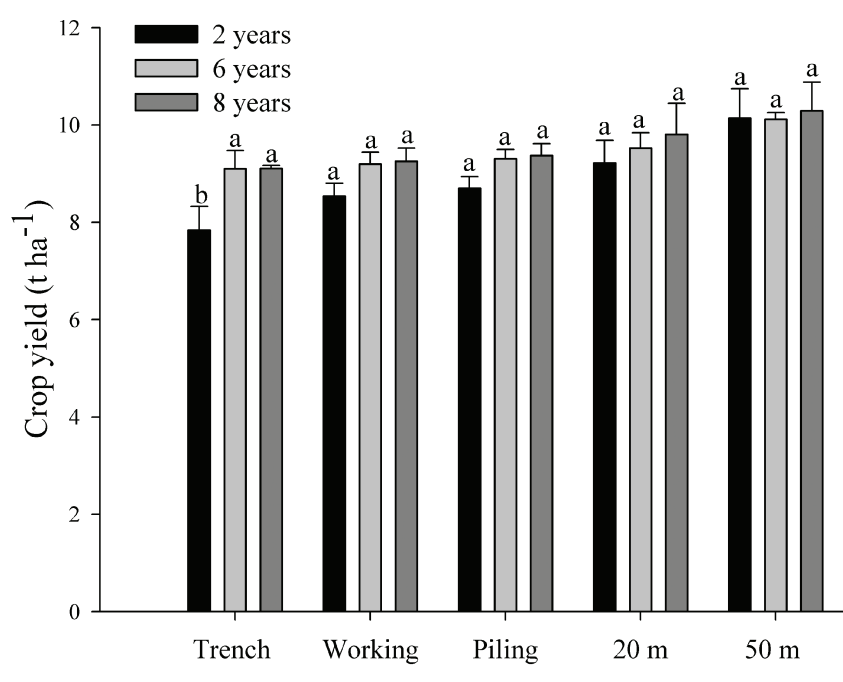

Fig. 4. Crop yields at areas over multiple time periods after pipeline installation were analyzed in Zhangye, Gansu province, China (Site C) in 2012: 8 yr for West-to-East Gas Pipeline I, 6 yr for the West Crude Oil Pipeline, and 2 yr for West-to-East Gas Pipeline II. Values followed by the same letter above standard error are not significantly different at the 0.05 level over different times after pipeline installation across the same pipeline zone according to Tukey's post-hoc test $(n=6)$.

\section{Agricultural Productivity Recovery over Multiple Time Periods after Pipeline Installation}

Corn yields in the trenched area, working zone, piling area, and $20 \mathrm{~m}$ from the West-to-East Gas Pipeline with a 2-yr recovery period were lower than those in the corresponding zones of pipelines with 6- (West Crude Oil Pipeline) and 8-yr (West-to-East Gas Pipeline I) recovery periods (Fig. 4). Specifically, corn yields in the trenched area following $2 \mathrm{yr}$ after pipeline installation were the lowest $\left(7.84 \mathrm{t} \mathrm{ha}^{-1}\right)$. However, corn yields in the pipeline RoW and $20 \mathrm{~m}$ area with $6 \mathrm{yr}$ after pipeline installation were similar to those at sites with $8 \mathrm{yr}$ after pipeline installation, with yields ranging from 9.10 to $9.81 \mathrm{t} \mathrm{ha}^{-1}$. There were no changes in the crop yields among three time periods after pipeline installation at $50 \mathrm{~m}$ area from pipeline indicating no land disturbance beyond that line.

Crop productivity was found to be similar to pre-installation period after 6 and 8 yr of pipeline installation (Table 3). For plant height, stem size, corncob length and leaf chlorophyll in disturbed areas of West-to-East Gas Pipeline II, the recovery was the relatively low. Crop characteristics such as stem size, corncob length, corncob's size and leaf chlorophyll in areas of trench, piling, working, and $20 \mathrm{~m}$ from the pipeline were higher for sites with $8 \mathrm{yr}$ after pipeline installation than that with 2 and $6 \mathrm{yr}$ after 
Table 3 Mean ( \pm standard deviation) of corn characteristics in areas over different times after pipeline installation along pipelines right-of-way in Zhangye, Gansu province, China (Site C). Values followed by the same letter are not significantly different at the 0.05 level over multiple time periods after pipeline installation across the same pipeline construction zone according to Tukey's Post-Hoc test $(n=6)$.

\begin{tabular}{|c|c|c|c|c|c|c|}
\hline Plot & $\begin{array}{c}\text { Time after pipeline } \\
\text { installation }\end{array}$ & $\begin{array}{l}\text { Plant } \\
\text { height }\end{array}$ & Stem size & Corncob length & Corncob size & Leaf chlorophyll \\
\hline & $\mathrm{yr}$ & 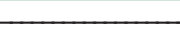 & 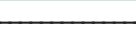 & 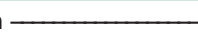 & - & \\
\hline \multirow[t]{3}{*}{ Trench } & 2 & $216.0 \pm 1.5 a$ & $2.9 \pm 0.1 \mathrm{a}$ & $26.4 \pm 3.5 a$ & $5.8 \pm 0.2 a$ & $33.0 \pm 1.9 a$ \\
\hline & 6 & $222.3 \pm 4.2 a$ & $3.0 \pm 0.1 \mathrm{a}$ & $27.0 \pm 1.0 \mathrm{a}$ & $5.7 \pm 0.1 \mathrm{a}$ & $33.7 \pm 2.7 a$ \\
\hline & 8 & $230.0 \pm 2.5 a$ & $3.0 \pm 0.2 a$ & $29.5 \pm 2.9 a$ & $6.0 \pm 0.3 a$ & $38.5 \pm 3.2 \mathrm{a}$ \\
\hline \multirow[t]{3}{*}{ Piling } & 2 & $221.7 \pm 0.7 b$ & $3.3 \pm 0.2 a$ & $27.1 \pm 1.1 \mathrm{a}$ & $6.1 \pm 0.4 a$ & $40.8 \pm 1.5 a$ \\
\hline & 6 & $226.7 \pm 1.5 a b$ & $3.4 \pm 0.1 \mathrm{a}$ & $27.5 \pm 1.3 a$ & $6.1 \pm 0.4 a$ & $42.5 \pm 1.4 a$ \\
\hline & 8 & $233.3 \pm 3.5 a$ & $3.6 \pm 0.0 \mathrm{a}$ & $28.4 \pm 1.4 \mathrm{a}$ & $6.3 \pm 0.2 a$ & $43.8 \pm 1.9 a$ \\
\hline \multirow[t]{3}{*}{ Working } & 2 & $228.0 \pm 6.2 \mathrm{a}$ & $3.0 \pm 0.1 \mathrm{a}$ & $27.8 \pm 1.0 \mathrm{a}$ & $6.2 \pm 0.4 a$ & $38.1 \pm 2.5 a$ \\
\hline & 6 & $235.3 \pm 3.2 \mathrm{a}$ & $3.0 \pm 0.1 \mathrm{a}$ & $28.5 \pm 0.5 a$ & $6.2 \pm 0.1 \mathrm{a}$ & $39.8 \pm 1.0 \mathrm{a}$ \\
\hline & 8 & $231.3 \pm 9.5 a$ & $3.2 \pm 0.1 \mathrm{a}$ & $29.4 \pm 0.9 a$ & $6.3 \pm 0.1 a$ & $4 I .4 \pm 4.0 \mathrm{a}$ \\
\hline \multirow[t]{3}{*}{$20 \mathrm{~m}$} & 2 & $240.3 \pm 3.3 a$ & $3.4 \pm 0.3 a$ & $30.1 \pm 1.5 a$ & $6.0 \pm 0.1 \mathrm{a}$ & $41.3 \pm 0.8 a$ \\
\hline & 6 & $244.7 \pm 3.4 \mathrm{a}$ & $3.4 \pm 0.3 a$ & $30.7 \pm 0.7 a$ & $6.5 \pm 0.2 \mathrm{a}$ & $42.4 \pm 0.8 a$ \\
\hline & 8 & $240.7 \pm 1.2 \mathrm{a}$ & $3.9 \pm 0.2 a$ & $31.2 \pm 1.0 \mathrm{a}$ & $6.8 \pm 0.5 a$ & $43.2 \pm 2.4 a$ \\
\hline \multirow[t]{3}{*}{$50 \mathrm{~m}$} & 2 & $245.0 \pm 1.2 \mathrm{a}$ & $3.2 \pm 0.2 a$ & $30.7 \pm 0.9 a$ & $6.5 \pm 0.2 a$ & $42.9 \pm 1.0 \mathrm{a}$ \\
\hline & 6 & $244.0 \pm 1.5 \mathrm{a}$ & $3.5 \pm 0.2 \mathrm{a}$ & $30.1 \pm 0.2 \mathrm{a}$ & $6.8 \pm 0.1 \mathrm{a}$ & $43.2 \pm 0.5 a$ \\
\hline & 8 & $244.7 \pm 2.8 a$ & $3.4 \pm 0.3 a$ & $30.3 \pm 0.3 a$ & $6.5 \pm 0.3 a$ & $44.3 \pm 0.4 a$ \\
\hline
\end{tabular}

pipeline installation. Crop characteristics were similar in all three time periods after pipeline installation at $50 \mathrm{~m}$ from pipeline.

\section{Correlations between Crop Characteristics and Soil Properties Relating to Pipeline Installation}

The RDA was used to study correlations between crop characteristics and soil properties to find the main factors affecting crop growth. The results showed that 10 measured environmental factors (AN, TN, TK, TP, TC, SOM, AP, WT, Clay, and $\mathrm{pH}$ ) explained about $54.1 \%$ of the variance in crop productivity, and the first two axes (Axis 1 and Axis 2) accounted for 53.0 and $0.8 \%$ of the explained variances, respectively (Fig. 5). Smaller angles between arrows of the environmental and crop factors suggested more correlation, and longer arrows mean that environmental factors contribute more to crop characteristics. Environmental arrows of AN, $\mathrm{TN}, \mathrm{TC}$, and SOM pointed approximately in the same direction (acute angle) as crop arrows, indicating a highly positive correlation. The AN had the most positive correlation with yield. Arrows of $\mathrm{pH}, \mathrm{TP}$, and Clay were in the opposite direction (obtuse angle) to almost all of the crop arrows, suggesting that these factors were negatively correlated and $\mathrm{pH}$ had the most negative correlation with crop characteristics.

Similarly, AN, TC, AP, and SOM had positive correlations with most crop characteristics in the Pearson Correlation analysis (Table 4). Correlations between AN and SOM with yield were 0.539 and 0.215 , significant at 0.01 and 0.05 levels, respectively. The WT, Clay, and $\mathrm{pH}$ had negative correlations with crop yield, which were $-0.056,-0.024$, and -0.346 , respectively. The negative correlation between $\mathrm{pH}$ and yield was significant at 0.05 level.

\section{DISCUSSION}

\section{Distance and the Effect of Pipeline Construction on Crop Productivity}

Linear development associated with large-scale corridors can have significant adverse effects on the agro-ecosystem (Um and Wright, 1998). In particular, expansion of vast networks of pipelines worldwide continues to cross and degrade farmland (Chen and Gao, 2006). An accurate documentation of the impact is necessary to determine and quantify the environmental effects of pipeline construction on

Table 4 Pearson Correlation between crop characteristics and soil properties. AN is alkali-hydrolyzable nitrogen, TN is total nitrogen, AP is available phosphorus, TP is total phosphorus, TK is total potassium, TC is total carbon, SOM is soil organic matter, and WT is soil water content.

\begin{tabular}{|c|c|c|c|c|c|c|c|c|c|c|c|}
\hline Crop characteristic & Coefficient & AN & $\mathrm{TN}$ & TK & TP & TC & SOM & AP & WT & Clay & $\mathrm{pH}$ \\
\hline \multirow[t]{2}{*}{ Yield } & $R^{2}$ & $0.539 * *$ & 0.248 & 0.025 & -0.194 & 0.168 & $0.215^{*}$ & 0.044 & -0.056 & -0.024 & $-0.346^{*}$ \\
\hline & $P$ & 0.002 & 0.186 & 0.896 & 0.305 & 0.375 & 0.020 & 0.817 & 0.77 I & 0.898 & 0.050 \\
\hline \multirow[t]{2}{*}{ Plant height } & $R^{2}$ & 0.183 & 0.112 & -0.135 & 0.239 & 0.010 & 0.283 & 0.282 & $-0.374^{*}$ & 0.009 & 0.040 \\
\hline & $P$ & 0.332 & 0.555 & 0.478 & 0.204 & 0.958 & 0.129 & 0.131 & 0.042 & 0.964 & 0.833 \\
\hline \multirow[t]{2}{*}{ Stem size } & $R^{2}$ & 0.033 & -0.045 & -0.019 & -0.333 & 0.103 & -0.047 & -0.227 & $0.362^{*}$ & -0.155 & -0.01 \\
\hline & $P$ & 0.862 & 0.812 & 0.922 & 0.072 & 0.589 & 0.806 & 0.228 & 0.049 & 0.412 & 0.940 \\
\hline \multirow[t]{2}{*}{ Corncob length } & $R^{2}$ & 0.316 & 0.210 & -0.049 & -0.073 & $0.379 *$ & 0.197 & 0.264 & -0.002 & $-0.369 *$ & -0.094 \\
\hline & $P$ & 0.089 & 0.266 & 0.799 & 0.703 & 0.039 & 0.297 & 0.158 & 0.993 & 0.045 & 0.621 \\
\hline \multirow[t]{2}{*}{ Corncob size } & $R^{2}$ & 0.217 & -0.045 & $-0.367 *$ & -0.055 & 0.003 & 0.041 & 0.226 & -0.059 & 0.074 & -0.023 \\
\hline & $P$ & 0.249 & $0.8 \mathrm{II}$ & 0.046 & 0.772 & 0.989 & 0.832 & 0.229 & 0.758 & 0.696 & 0.903 \\
\hline \multirow[t]{2}{*}{ Leaf chlorophyll } & $R^{2}$ & $0.362^{*}$ & 0.273 & 0.232 & -0.064 & $0.500 * *$ & 0.173 & 0.086 & $0.539 * *$ & $0.462^{*}$ & -0.021 \\
\hline & $P$ & 0.050 & 0.145 & 0.217 & 0.738 & 0.005 & 0.361 & 0.652 & 0.002 & 0.010 & 0.910 \\
\hline
\end{tabular}

* Means correlation is significant at 0.05 level.

*** Means correlation is significant at 0.01 level. 
crop productivity. Pipeline construction requires a $30-\mathrm{m}$ wide corridor from which the topsoil is stripped to accommodate equipment (Desserud et al., 2010). The visible scar on agricultural land is considered a major environmental effect of the pipeline construction (Sahin and Kurum, 2009). It is indicated that pipeline installation disturbance was different in three construction zones because of different construction activities, confirming our hypothesis that disturbance intensity would be changed in different pipeline zones. Our results showed that crop yield, height, and leaf chlorophyll levels were significantly decreased in the trenched area. Leaf etiolation in the trenched area obviously showed an intensive disturbance as expected (Fig. 6). Soil horizon mixing decreased soil nutrient in the trenched area (Yu et al., 2010), and soil affected by trench was characterized by low levels of AN, TP, and SOM. During the operational period, soil temperature increased by 1 to $2^{\circ} \mathrm{C}$ in the trenched area compared to other zones. Soil nutrient decline and soil temperature anomaly may be the reasons for the visible etiolated of crop leaf in the trenched area. Although working and piling areas had higher crop yields than that for the trenched area, they were still significantly lower than those at 50 and $100 \mathrm{~m}$. Surface soil spoiling and soil compaction during construction may be the main reasons for reduction in crop productivity (Coiffait-Gombault et al., 2011). Soil properties of AN, AP, TN, TP, SOM, and WT at $20 \mathrm{~m}$ from pipeline were lower than those beyond $50 \mathrm{~m}$. Crop yield, plant height, corncob length and leaf chlorophyll were also higher at 50 and $100 \mathrm{~m}$ than that at $20 \mathrm{~m}$, indicating that disturbed zone extended between 20 to $50 \mathrm{~m}$ distance from pipeline. Crop

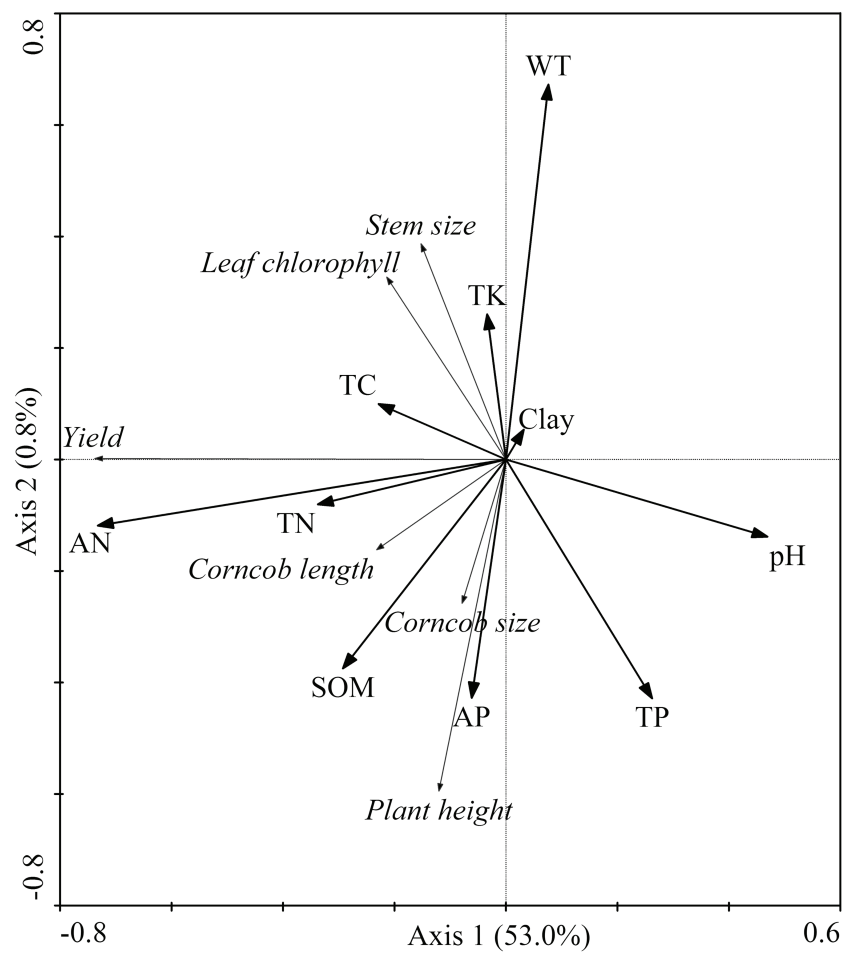

Fig. 5. The redundancy analysis (RDA) of the crop and soil relationship using 6 crop properties and 10 soil variables. The angle between two arrows is proportional to the degree of their correlation and the length of an arrow is interpreted as its relative contribution. AN is alkali-

hydrolyzable nitrogen, TN is total nitrogen, AP is available phosphorus, TP is total phosphorus, TK is total potassium, TC is total carbon, SOM is soil organic matter, and WT is soil water content. properties at $50 \mathrm{~m}$ from pipeline were almost the same as those at $100 \mathrm{~m}$, and yields at these areas were similar, suggesting no disturbance. The disturbance of pipeline installation on agricultural system suggested a gradient that agricultural productivity improved as distance from pipeline increased.

\section{Agricultural Productivity Improvement over Time after Pipeline Installation}

A previous study (Culley and Dow, 1988) documented that the corn yield in the pipeline's RoW increased over 5-yr periods after pipeline installation, it was still significantly lower than the yields of undisturbed adjacent cropland. The quantitative research on agricultural productivity improvement from pipeline disturbance can contribute to implementation of more accurate follow-up environmental assessments. An assessment of plant rehabilitation along the oil and gas pipelines found that vegetation cover restored to half the level of the undisturbed state after a 3-yr cycle (Bayramov et al., 2012). The effect on soil properties may be moderate during the first 2- to 3-yr periods after the pipeline construction due to natural recovery and agricultural management (Soon et al., 2000b). However, yield reduction was still significant in the trenched area after $2 \mathrm{yr}$ of pipeline installation. Crop productivities in pipeline RoW 6 and 8 yr after pipeline construction were higher compared to that after $2 \mathrm{yr}$ of pipeline construction. These results indicate that agricultural productivity can be expected to be improved over time, thus confirming our hypothesis.

\section{Soil Management Practices during the Pipeline Installation Process}

The influence of pipeline construction on agricultural productivity is an indirect and continuous process. Soil systems that provide critical support for crop productivity are adversely affected by pipeline installation. Our results showed that $\mathrm{AN}, \mathrm{SOM}$, and $\mathrm{pH}$, which are important factors for crop growth, were sensitive to pipeline disturbance. A study was performed in southern California focused on effects of pipeline construction on soil chemistry, and results showed that levels of AN, TN, and SOM were significantly less along the pipeline corridor than that in the adjacent undisturbed areas (Zink et al., 1995). Irregular stacking of spoil reduces SOM on the topsoil after pipeline installation by mixing more fertile topsoil with less fertile subsoil. This resulted in lower

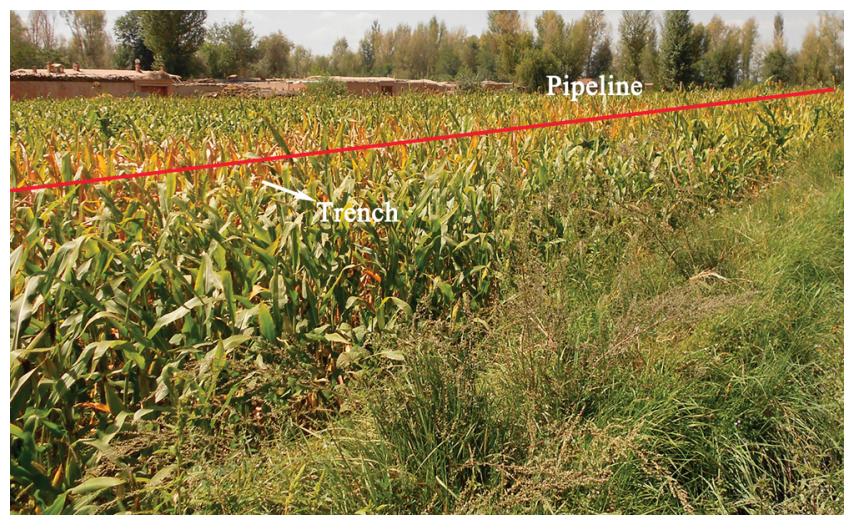

Fig. 6. The visible etiolated of crop leafs in the trenched area indicate an intense disturbance in this pipeline zone. 
$\mathrm{N}$ supply from mineralized organic matter, which together with a highly compacted surface soil layer and higher $\mathrm{pH}$, may be responsible for yield reduction (Olson and Doherty, 2012). Soon et al. (2000a) reported that crop yield decreased by more than half in the year of pipeline construction and that the effect of pipeline disturbance on crop productivity could be attributed to deterioration of soil fertility. Similar results were found in our study that crop characteristics showed most corrections with $\mathrm{AN}, \mathrm{SOM}$, and $\mathrm{pH}$, and these soil properties were significantly affected by pipeline installation. These results indicated that soil management during the installation process is critical. It is important to store removed topsoil separately from subsurface soil as shown in Fig. 2 and place topsoil back on top of subsurface soil following backfill.

\section{CONCLUSIONS}

Determination of the affected area and recovery period can have important repercussions for pipeline EIAs. This study indicated that intensity of disturbance declined as distance from the pipeline increased. The most significant disturbance from pipeline installation occurred within the $20-\mathrm{m}$ zone from the pipeline. Agricultural productivity was improved over times after pipeline installation. Corn yields in the pipeline RoW 6 and 8 yr after pipeline installation were higher than that of $2 \mathrm{yr}$ after pipeline installation as expected. Necessary mitigation measures, such as storing removed soil separately and backfilling it sequentially, should be implemented during pipeline installation period to reduce the impacts of pipeline construction on crop yields. In a follow-up study, remote sensing combined with transect sampling will be applied to study the effects of large-scale pipeline projects on agricultural productivity.

\section{ACKNOWLEDGMENTS}

This work was financially supported by the Industry Research Project on Environmental Protection (201209029).

\section{REFERENCES}

Bayramov, E., M. Buchroithner, and E. McGurty. 2012. Quantitative assessment of vegetation cover and soil degradation factors within terrain units for planning, monitoring and assessment of renaturation along oil and gas pipelines. Geocarto Int. 27:535-555. doi:10.1080/10106049.2011.648662

Boboye, O.A., and I.O. Abumere. 2014. Environmental impact of elemental concentration and distribution in waters, soils and plants along the LokojaAbuja pipeline routes of Bida Basin, northwestern Nigeria. J. Afr. Earth Sci. 99:694-704. doi:10.1016/j.jafrearsci.2014.04.008

Chen, L.D., and Q.C. Gao. 2006. Chance and challenge for China on ecosystem management: Lessons from the Westto-East Pipeline Project construction. Ambio 35:91-93. doi:10.1579/0044-7447(2006)35[91:CACFCO]2.0.CO;2

Coiffait-Gombault, C., E. Buisson, and T. Dutoit. 2011. Hay transfer promotes establishment of Mediterranean steppe vegetation on soil disturbed by pipeline construction. Restor. Ecol. 19:214-222. doi:10.1111/j.1526-100X.2010.00706.x
Cornfield, A.H. 1960. Ammonia released on treating soils with $\mathrm{N}$ sodium hydroxide as a possible means of predicting the nitrogen-supplying power of soils. Nature (London) 187:260-261. doi:10.1038/187260a0

Cui, B.S., S.Q. Zhao, K.J. Zhang, S.C. Li, S.K. Dong, and J.H. Bai. 2009. Disturbance of Dabao highway construction on plant species and soil nutrients in Longitudinal Range Gorge Region (LRGR) of Southwestern China. Environ. Monit. Assess. 158:545-559. doi:10.1007/ s10661-008-0605-y

Culley, J.L.B., and B.K. Dow. 1988. Long-term effects of an oil pipeline installation on soil productivity. Can. J. Soil Sci. 68:177-181. doi:10.4141/ cjss88-018

De'Ath, G. 2002. Multivariate regression trees: A new technique for modeling species-environment relationships. Ecology 83:1105-1117. doi: $10.2307 / 3071917$.

Desserud, P., C.C. Gates, B. Adams, and R.D. Revel. 2010. Restoration of foothills rough fescue grassland following pipeline disturbance in southwestern Alberta. J. Environ. Manage. 91:2763-2770. doi:10.1016/j. jenvman.2010.08.006

Doherty, V.F., and A.A. Otitoloju. 2013. Monitoring of soil and groundwater contamination following a pipeline explosion and petroleum product spillage in Ijegun, Lagos Nigeria. Environ. Monit. Assess. 185:4159-4170. doi:10.1007/s10661-012-2858-8

João, E. 2002. How scale affects environmental impact assessment. Environ. Impact Assess. Rev. 22:479-491. doi:10.1016/S0195-9255(02)00016-1.

Karstens, S.A.M., P.W.G. Bots, and J.H. Slinger. 2007. Spatial boundary choice and the views of different actors. Environ. Impact Assess. Rev. 27:386-407. doi:10.1016/j.eiar.2007.02.002

Landsburg, S. 1989. Effects of pipeline construction on chernozemic and solonetzic A and B Horizons in central Alberta. Can. J. Soil Sci. 69:327336. doi:10.4141/cjss89-033

Olson, E.R., and J.M. Doherty. 2012. The legacy of pipeline installation on the soil and vegetation of southeast Wisconsin wetlands. Ecol. Eng. 39:53-62. doi:10.1016/j.ecoleng.2011.11.005

Sahin, S., and E. Kurum. 2009. Landscape scale ecological monitoring as part of an EIA of major construction activities: Experience at the Turkish section of the BTC crude oil pipeline project. Environ. Monit. Assess. 156:525537. doi:10.1007/s10661-008-0502-4

Shi, P., J. Xiao, Y.F. Wang, and L.D. Chen. 2014. The effects of pipeline construction disturbance on soil properties and restoration cycle. Environ. Monit. Assess. 186:1825-1835. doi:10.1007/s10661-013-3496-5

Sims,J.R., andV.A.Haby.1971.Simplifiedcolorimetricdeterminationofsoilorganic matter. Soil Sci. 112:137-141. doi:10.1097/00010694-197108000-00007

Soon, Y.K., M.A. Arshad, W.A. Rice, and P. Mills. 2000b. Recovery of chemical and physical properties of boreal plain soils impacted by pipeline burial. Can. J. Soil Sci. 80:489-497. doi:10.4141/S99-097

Soon, Y.K., W.A. Rice, M.A. Arshad, and P. Mills. 2000a. Effect of pipeline installation on crop yield and some biological properties of boreal soils. Can. J. Soil Sci. 80:483-488. doi:10.4141/S99-096

Swinton, S.M., F. Lupi, G.P. Robertson, and S.K. Hamilton. 2007. Ecosystem services and agriculture: Cultivating agricultural ecosystems for diverse benefits. Ecol. Econ. 64:245-252. doi:10.1016/j.ecolecon.2007.09.020

Um, J.S., and R. Wright. 1998. A comparative evaluation of video remote sensing and field survey for revegetation monitoring of a pipeline route. Sci. Total Environ. 215:189-207. doi:10.1016/S0048-9697(97)00340-9

Yu, X.F., G.P. Wang, Y.C. Zou, Q.A. Wang, H.M. Zhao, and X.G. Lu. 2010. Effects of pipeline construction on wetland ecosystems: Russia-China Oil Pipeline Project (Mohe-Daqing Section). Ambio 39:447-450. doi:10.1007/ s13280-010-0055-y

Zink, T.A., M.F. Allen, B. HeindlTenhunen, and E.B. Allen. 1995. The effect of a disturbance corridor on an ecological reserve. Restor. Ecol. 3:304-310. doi:10.1111/j.1526-100X.1995.tb00098.x 